\title{
Conservation status of the Natura 2000 habitat 3110 in Poland: Monitoring, classification and trends
}

\author{
Agnieszka Kolada ${ }^{1}$, Ryszard Piotrowicz ${ }^{2}$, Elżbieta Wilk-Woźniak ${ }^{3}$, Piotr Dynowski ${ }^{4}$, Piotr Klimaszyk $^{2^{*}}$ \\ ${ }^{1}$ Department of Freshwater Protection, Institute of Environmental Protection - National Research Institute, Kolektorska 4, 01-692 \\ Warsaw, Poland, e-mail: a.kolada@ios.edu.pl \\ ${ }^{2}$ Department of Water Protection, Faculty of Biology, Adam Mickiewicz University. Umultowska 89, 61-614 Poznań, Poland, \\ e-mail: pklim@amu.edu.pl (*corresponding author); ryszardp@amu.edu.pl \\ ${ }^{3}$ Institute of Nature Conservation, Polish Academy of Sciences, al. Adama Mickiewicza 33, 31-120 Kraków, Poland, \\ e-mail: wilk@iop.krakow.pl \\ ${ }^{4}$ Department of Botany and Nature Protection, University of Warmia and Mazury in Olsztyn, Plac Łódzki 1, 10-727 Olsztyn, Poland, \\ e-mail: piotr.dynowski@uwm.edu.pl
}

\begin{abstract}
Soft water lakes, or so-called lobelia lakes, which are inhabited by a specific vegetation composed of isoetids, have been subjected to intense research aimed at evaluating their condition and conservation status for many years in Poland. At the time of Poland's accession to the European Union and the implementation of the EU Habitats Directive, these lakes were classified as natural habitat 3110 . In accordance with the provision of the Habitat Directive a comprehensive methodology for monitoring and classification of the state of this habitat has been developed. Using this methodology, two monitoring trials (in 2009-2010 and again in 2016-2017) were carried out at 45 and 43 sites of the 3110 natural habitat, respectively. These studies confirm the high sensitivity of these poorly buffered aquatic ecosystems to all external influences, both natural and anthropogenic. The overall conservation status of the 3110 habitat in Poland showed a relatively high stability, with similar proportions of sites classified as favourable (FV), unfavourable inadequate (U1) and unfavourable bad (U2) between 2009-2010 (35\%, 49\% and 16\%, respectively) and 2016-2017 (33\%, 56\% and 11\%, respectively). Out of 43 sites examined in 2016-2017, 29 remained unchanged compared with the results of the previous survey concerning their overall status. Results of the monitoring research also allow for the observation and evaluation of mechanisms and directions of changes in the functioning of these ecosystems. Based on the experiences from two series of monitoring conducted so far, the methodology has been assessed as appropriate for the assessment of the conservation status of the 3110 natural habitat, however, some modifications and additions have been suggested.
\end{abstract}

Key words: Natura 2000, nature habitat 3110, soft water lakes, monitoring, isoetids

\section{Introduction}

In Poland, the term "lobelia lake" (LL) is commonly used for a lake where characteristic plant species (isoetids) occur together or separately, i.e., water lobelia Lobelia dortmanna, quillwort Isoëtes lacustris, European shoreweed Littorella uniflora, alternate watermilfoil Myriophyllum alterniflorum and, more rarely, floating water-plantain Luronium natans (Kraska et al. 1996). These lakes are relatively rare in the country (Kraska 2004; Wilk-Woźniak et al. 2012) and the lobelia vegetation is of high conservation importance (Smolder et al. 2002).

Since the mid-twentieth century, Polish LLs have been subjected to intense research aimed at exploring their occurrence, ecological status and threats (Bociąg 2003; Bociag and Borowiak 2016; Kraska 1994a,b; Kraska et al. 1996, 2013; Kraska and Piotrowicz 2000; Szmal and Szmal 1965; Szmeja 1992, 1996; 1997). Based on these studies, a complete inventory of LLs has been performed and the main abiotic and biotic features of these ecosystems have been recognized. There are approximately 170 lobelia lakes of an area greater than 1 ha identified in Poland. They are typically small ecosystems with closed basins and only a few of them have an inflow of water from temporary water courses. The isoetids from the Lobelion dortmannae and Isoetion lacustris alliances occur only in waters with low mineralization and low calcium content. The presence of specific vegetation and its good ecological condition depend 
on high water transparency, $\mathrm{pH}$ ranging from about 5.5 to 7.5 , electrolytic conductivity lower than $100 \mu \mathrm{S}$ $\mathrm{cm}^{-1}$, a slight amount of calcium, low concentration of nitrogen and phosphorus, lack of algal blooms and characteristic plankton composition with mixotrophic taxa, chrysophytes, dinophytes or cryptophytes or tiny green algae.

Based on the physical and chemical properties of these waters and the proportion of characteristic plant species, LLs have been temporarily divided into four groups/subtypes: (i) dystrophic (oligohumic and polyhumic), (ii) nutrient-balanced, (iii) eutrophicated and (iv) degraded (Kraska 2004). This division reflects the threats and directions of the evolution of LLs', both natural and human-induced. Because of their small surface areas and usually limited depths, LLs are particularly vulnerable to adverse impacts, especially those resulting from human activities. Changes in hydrological systems through draining peat bogs near the lakes, dumping humic water into the lakes, liming and fish stocking lead to changes in the physicochemical properties of their waters and, as a consequence, to the disappearance of characteristic vegetation. LLs are at risk either due to eutrophication or dystrophication. Therefore, this habitat is unstable, susceptible to changes and can rapidly degrade and disappear. The favourable conservation status of LLs depends primarily on maintaining the specificity of landscape in the form of natural associations in the catchment areas of the lakes, with its most essential elements such as pine forests, acidic beech forests, Sphagnum bogs and highmoor peatbogs.

EU legislation and a number of international conventions, in particular the Convention on Biological Diversity (UN 1992), oblige member states to identify and monitor the components of biological diversity, paying particular attention to those requiring urgent conservation measures and those which offer the greatest potential for sustainable use. The provisions of the Convention were specified in the Council Directive 92/43/EEC of 21 May 1992 on the conservation of natural habitats and of wild fauna and flora (the so-called Habitats Directive; EC 1992), which determined the legal framework for creating the European ecological network Natura 2000, the main instrument for maintaining biological diversity in the EU territory. Article 11 of the Habitats Directive provides that: Member States shall undertake surveillance of the conservation status of the natural habitats and species referred to in Article 2 with particular regard to priority natural habitat types and priority species. Also, in accordance with Article 17 of the Directive: Every six years [...], Member States shall draw up a report on the implementation of the measures taken under this Directive. This report shall include, in particular, information concerning conserva- tion measures [...] as well as an evaluation of the impact of those measures on the conservation status of the natural habitat types.

According to the Habitat Directive, nature habitat 3110 "Oligotrophic waters containing very few minerals of sandy plains (Littorelletalia uniflorae)" consists of "oligotrophic waters with few minerals and base poor, with an aquatic to amphibious low perennial vegetation belonging to the Littorelletalia uniflorae order, on oligotrophic soils of lake and pond banks (sometimes on peaty soils). This vegetation consists of one or more zones, dominated by Littorella, Lobelia dortmana or Isöetes, although not all zones may be found at a given site" (EC 2013). The Polish LLs, thus, fully correspond to the definition of EU habitat 3110 and are required to be identified and monitored under the provision of the European legislation.

In line with the recommendations of Article 11 of the Habitats Directive, in the period 2009-2011 a suite of methods for monitoring natural habitats (Mróz 2013), including habitat 3110 (Wilk-Woźniak et al. 2012, 2013) in Poland were developed and the sites of nature habitat 3110 have been identified. Two series of monitoring surveys of these sites, the first one in 20092010 and the second in 2016-2017, have been conducted within the State Monitoring Programme performed under the commission of the Chief Inspectorate of Environmental Protection. The aim of this paper is to present the main methodological aspects and the results of the monitoring of nature habitat 3110 in Poland over these two study periods.

\section{Methods for monitoring of the nature habitat 3110 in Poland}

\section{Field surveys}

In 2009-2010, 45 sites representing the 3110 nature habitat, which constitutes about $25 \%$ of all LLs in Poland, were assigned. They are all located in the Polish Lowlands and represent all areas of LL occurrence, i.e., Kołobrzeg Coastland, West-Pomerania Lakeland, South-Pomerania Lakeland, and East-Pomerania Lakeland, as well as three lakes located on the eastern boundary of the Olsztyn Lakeland (Fig. 1). Moreover, one lake representing habitat 3110, Wielki Staw in Karkonosze (Giant Mountains), is located in the mountainous area in the southern part of the country. Given the limited geographic scope of the habitat in Poland, both the number and location of the sites seem to well represent the habitat resources of 3110 .

All 45 sites were monitored in the period of 20092010 in accordance with the official methodology described in detail in Wilk-Woźniak et al. (2012, 2013). Monitoring of the habitat conservation status was car- 


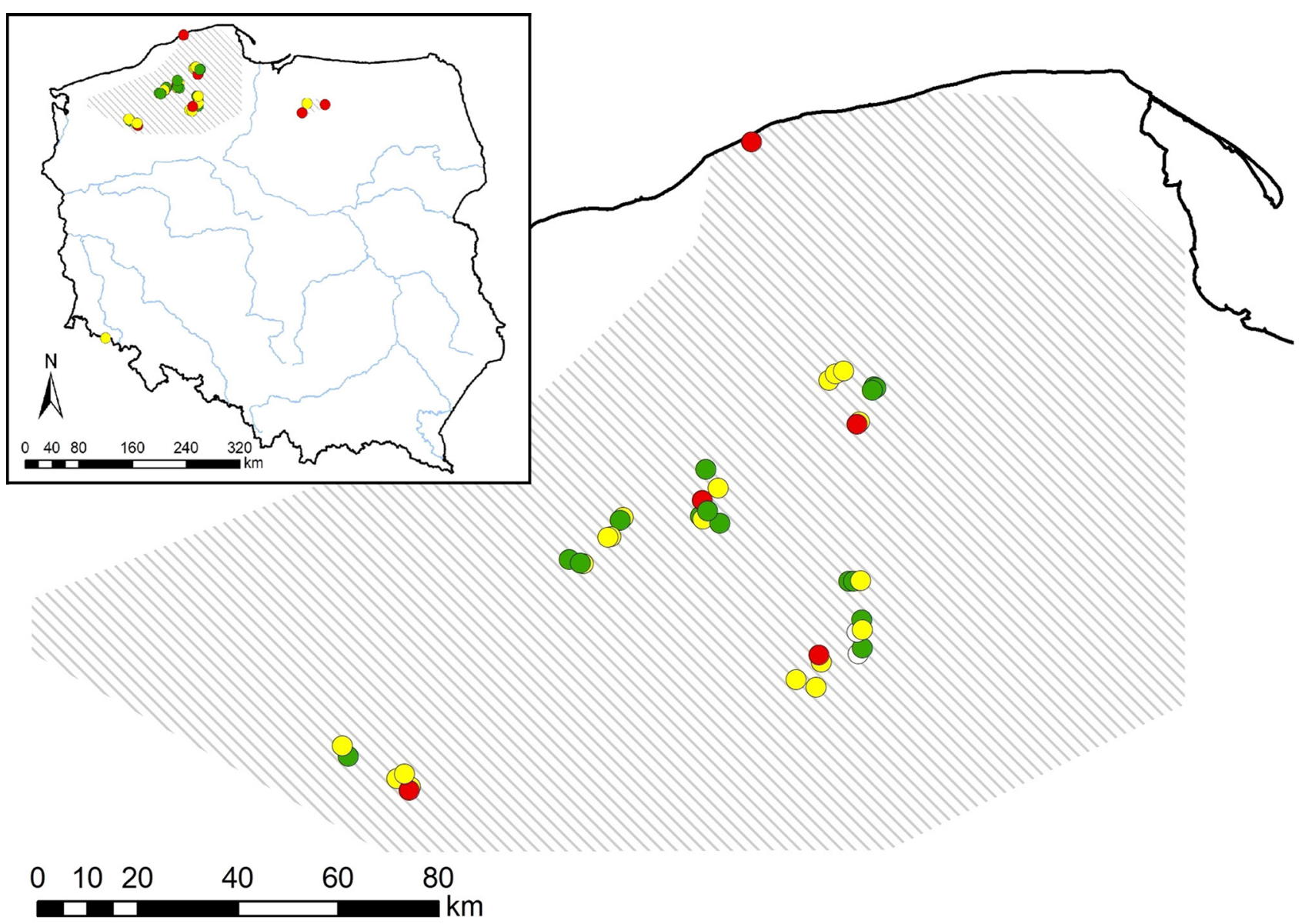

Fig. 1. Distribution and conservation status (green dots - favourable (FV), yellow - inadequate (U1) and red - bad (U2)) of monitoring sites of the habitat 3110 (Lobelia lakes) in Poland. Shaded area indicates the geographical range of the habitat, conservation status

ried out in summer, between July and September, not earlier than at the beginning of July and not later than mid-September. At all the monitored sites, the presence and condition of the plant communities characteristic of lobelia lakes were assessed and the occurrence of rare, protected or characteristic species for the habitat were noted within a fixed transect or transects. Moreover, the species indicating habitat degradation were identified when present (see Table 1 for methodological details). The selected water quality parameters were determined in situ, i.e., water colour, transparency (visibility of the Secchi disc), conductivity, and reaction ( $\mathrm{pH})$. For phytoplankton analyses (auxiliary parameter), water samples were taken from the surface layer (ca. $0.5-1.0 \mathrm{~m}$ ) and stabilized with Lugol's solution. Samples for the determination of water physicochemical parameters and plankton samples were collected from the deepest point of each lake, usually situated in the centre of the lake or its evidently distinct part, and not from the littoral zone. All surveys were performed with the use of a boat.

In addition to the above, the current impacts on the natural habitat at the monitored locations as well as predicted threats were recorded. A list of coded impacts in accordance with Annex E to the standard Data Form for Natura 2000 areas was used. Determination of intensity (high A, moderate B, low C) and the type of effect (negative -, positive + , and neutral 0 ) for a given impact or threat as well as a short description were indicated.

In 2016-2017, monitoring was repeated on 43 sites using the same methodology. Two sites were excluded as they are surveyed for their conservation status within networks other than the State Monitoring Programme. If the transect marked in previous studies was moved, the new geographical coordinates were identified. In addition to the above information, the size of the community was assessed to see whether it was reduced, expanded or remained comparable with the size of the community examined previously.

\section{Assessment and classification}

Assessment of the conservation status of the habitat is based on three parameters: (i) Habitat area, (ii) Specific structure and functions and (iii) Conservation 
Table 1. Evaluation of status parameters and indices of specific structure and functions for natural habitat 3110 Lobelia lakes (Oligotrophic waters containing very few minerals of sandy plains) (modified after Wilk-Woźniak et al. 2013)

\begin{tabular}{|c|c|c|c|c|}
\hline \multirow{2}{*}{\multicolumn{2}{|c|}{$\begin{array}{l}\text { Param } \\
\text { Habitat area }\end{array}$}} & FV (favourable) & U1 (unfavourable inadequate) & U1 (unfavourable bad) \\
\hline & & $\begin{array}{l}\text { The area has not changed from the } \\
\text { previous study }\end{array}$ & A decline in habitat area observed & $\begin{array}{l}\text { The habitat disappeared from } \\
\text { the monitored location }\end{array}$ \\
\hline \multirow{9}{*}{ 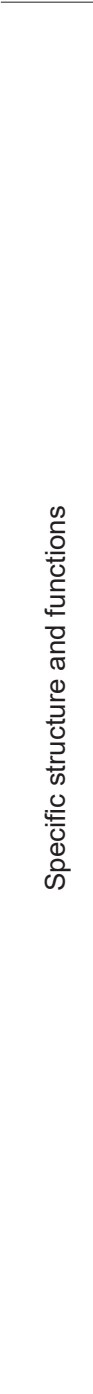 } & $\begin{array}{l}\text { Characteristic } \\
\text { combination of } \\
\text { communities within } \\
\text { the transect }\end{array}$ & $\begin{array}{l}\text { Patches of Lobelietum } \\
\text { dortmannae, Isoetetum lacustris } \\
\text { or Myriophylletum alterniflori } \\
\text { association predominate. High } \\
\text { diversity of species characteristic of } \\
\text { LLs, great or massive occurrence } \\
\text { of characteristic species: Lobelia } \\
\text { dortmanna, Isoëtes lacustris, } \\
\text { Isoëtes echinospora, Littorella } \\
\text { uniflora, Myriophyllum alterniflorum, } \\
\text { Luronium natans }\end{array}$ & $\begin{array}{l}\text { The vegetation of the Isoeto- } \\
\text { Lobelietum asssociation } \\
\text { scarcely present, domination } \\
\text { of Myriophyllum spicatum over } \\
\text { Myriophyllum alterniflorum. } \\
\text { Little diversity among species } \\
\text { characteristic of LLs, characteristic } \\
\text { species scarce or sporadic }\end{array}$ & $\begin{array}{l}\text { Species characteristic of } \\
\text { Lobelia lakes recorded earlier } \\
\text { absent form a lake or occur } \\
\text { as single individuals or as } \\
\text { accompanying species in } \\
\text { communities of plants typical } \\
\text { of eutrophic or dystrophic } \\
\text { lakes }\end{array}$ \\
\hline & $\begin{array}{l}\text { Species indicating } \\
\text { degeneration of the } \\
\text { habitat }\end{array}$ & $\begin{array}{l}\text { Lack of species indicating } \\
\text { degeneration of the habitat }\end{array}$ & $\begin{array}{l}\text { Species indicating degeneration } \\
\text { of the habitat occur as single } \\
\text { individuals }\end{array}$ & $\begin{array}{l}\text { Species indicating } \\
\text { degeneration of the habitat } \\
\text { such as Nuphar lutea, } \\
\text { Ceratophyllum demersum, } \\
\text { Myriophyllum spicatum, frogbit } \\
\text { Hydrocharis morsus-ranae } \\
\text { increase in their proportions in } \\
\text { the communities }\end{array}$ \\
\hline & Water colour & Transparent, livid-blue or blue & $\begin{array}{l}\text { Blue with a green or yellow-green } \\
\text { tinge }\end{array}$ & Brown or visibly green \\
\hline & Water pH & pH 5.5-7.5 & $\mathrm{pH}<5.5$ to 4.5 or $\mathrm{pH}>7.5$ to 8.5 & $\mathrm{pH}<4.5$ or $\mathrm{pH}>8.5$ \\
\hline & Conductivity & $<100 \mu \mathrm{S} \mathrm{cm} \mathrm{cm}^{-1}$ & $100-250 \mu \mathrm{S} \mathrm{cm}^{-1}$ & $>250 \mu \mathrm{S} \mathrm{cm}-1$ \\
\hline & Water transparency & Secchi disc depth $>3.5 \mathrm{~m}$ & Secchi disc depth 1.5-3.5 m & Secchi disc depth $<1.5 \mathrm{~m}$ \\
\hline & $\begin{array}{l}\text { Phytoplankton } \\
\text { (auxiliary indicator) }\end{array}$ & $\begin{array}{l}\text { In the dystrophic LLs, many } \\
\text { mixotrophic taxa, chrysophytes } \\
\text { or tiny green algae and/ } \\
\text { or chroococcus blue-green } \\
\text { algae occur. Also possible is } \\
\text { the domination of dinophytes } \\
\text { or cryptophytes as well as the } \\
\text { occurrence of Gonyostomum } \\
\text { semen (Raphidophyceae) }\end{array}$ & $\begin{array}{l}\text { Co-domination of blue-green and } \\
\text { green algae }\end{array}$ & $\begin{array}{l}\text { Domination of filamentous } \\
\text { blue-green algae, or those } \\
\text { of the Microcystis and } \\
\text { Woronichinia genera, blue- } \\
\text { green algal blooms }\end{array}$ \\
\hline & $\begin{array}{l}\text { Zooplankton } \\
\text { (auxiliary indicator) }\end{array}$ & $\begin{array}{l}\text { Rotatoria and Cladocera occur } \\
\text { often but at low densities, few } \\
\text { Copepoda, prevalence of large } \\
\text { forms of filtrators/cladocerans } \\
\text { (Daphnia) }\end{array}$ & $\begin{array}{l}\text { Presence of Rotatoria and small } \\
\text { Cladocera (Bosmina, Chydorus) }\end{array}$ & $\begin{array}{l}\text { Domination of Rotatoria, } \\
\text { particularly Keratella } \\
\text { cochlearis f. tecta }\end{array}$ \\
\hline & $\begin{array}{l}\text { Overall structure and } \\
\text { functions }\end{array}$ & All FV or one U1 & Two or three U1, none U2 & One or more U2 \\
\hline \multicolumn{2}{|c|}{ Conservation prospects } & $\begin{array}{l}\text { Conservation prospects for the } \\
\text { habitat are good or excellent, no } \\
\text { significant impact of threatening } \\
\text { factors predicted, survival of the } \\
\text { habitat in longer time perspective is } \\
\text { very probable }\end{array}$ & Intermediate combinations & $\begin{array}{l}\text { Conservation prospects for } \\
\text { the habitat are bad, strong } \\
\text { impact of threatening factors } \\
\text { is predicted or observed, } \\
\text { (draining of the area, improper } \\
\text { management of lakes and } \\
\text { land use in the catchment } \\
\text { areas), no survival of the } \\
\text { habitat can be guaranteed in } \\
\text { the long term }\end{array}$ \\
\hline \multicolumn{2}{|c|}{ Overall status } & All FV & One or more $\mathrm{U} 1$, none $\mathrm{U} 2$ & One or more U2 \\
\hline
\end{tabular}

prospects that are combined into the final assessment result - overall status. The parameter Specific structure and functions of the 3110 nature habitat consists of six cardinals, with the first two cardinals being biocenotic (describing the condition of the plant complex) and the other four determining habitat conditions (Table 1).
In addition, an auxiliary parameter, plankton, that includes phyto- and zooplankton, is considered.

A three-level scale was defined for all parameters and indicators: FV favourable status; U1 unfavourable inadequate; U2 unfavourable bad. Additionally, the mark XX indicates unknown status. The scale of 
assessments is the same as that adopted by the European Commission for the purposes of reporting on the conservation status of habitats and species in biogeographical regions. In the overall assessment the rule "one-out-all-out" is adopted, which means that the final status is determined by the parameter assessed as having the worst status.

All sites surveyed in both monitoring trials were classified as representing either FV, U1 or U2 status for all parameters and indicators as well as for the overall conservation status and the classification results of 2009-2010 and 2016-2017 were compared.

\section{Monitoring results of the 3110 nature habitat conservation status}

\section{Overall protection status and its parameters and indicators}

The "Overall assessment of habitat conservation status" of the 3110 habitat sites surveyed in 2016-2017 indicated that $35 \%$ of the sites are in favourable conservation status (FV), $49 \%$ in unsatisfactory (U1) and $16 \%$ in bad condition (U2) (Fig. 2). The main reason for the poor assessment of almost all sites assessed as U2 was the poor condition of the characteristic vegetation (Specific structure and functions parameter), although at several sites complete degradation of the habitat in terms of all or most of the assessed parameters has been reported. The main cause of the habitat degradation was eutrophication or dystrophisation.

Compared with the previous habitat surveys, the overall conservation status of six sites improved, while eight declined (Table 2). The proportion of sites in the particular classes of conservation status in the previous studies (33\% FV, 56\% U1 and 11\% U2) was similar to what was observed in the current surveys, which may indicate a relatively stable protection status of nature habitat 3110 in Poland.

The "Habitat area" parameter indicated a generally good state of nature habitat 3110 in both study periods (98\% and $84 \%$ of sites rated FV, respectively; Fig. 2), although in 2016-2017 six sites were given a lower class compared to the previous study. Adverse changes in the habitat surface resulted from the deterioration of water quality (mainly eutrophication or disturbed reservoirs)

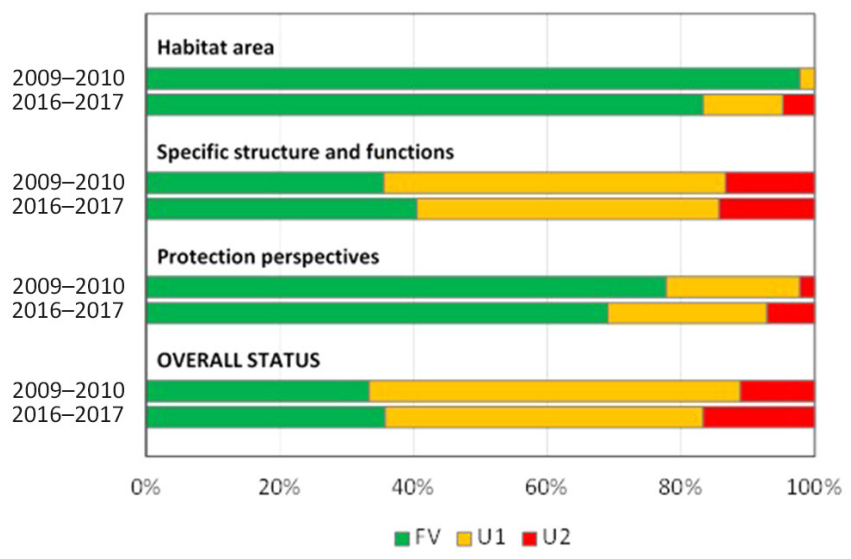

Fig. 2. The proportion of 3110 sites classified as being in favourable (FV), inadequate (U1) or bad (U2) status based on the particular parameters resulting from the monitoring surveys performed in the years 2009-2010 $(\mathrm{n}=45)$ and 2016-2017 $(\mathrm{n}=43)$

and associated habitat depletion. The other 37 sites retained the FV rating.

In terms of the "Specific structure and functions" parameter, the 3110 habitat in Poland represents all three states in 2016-2017 with proportions of $42 \%$ of sites FV, 44\% U1 and 14\% U2 (Fig. 2). Overall, this parameter showed a relatively high level of stability between the two periods, as when surveyed in 2009-2010 FV ratings were given at $36 \%$ of the sites, U1 at $51 \%$ and U2 at 13\%. Concerning indicators that describe the "Specific structure and functions", most of them indicated a relatively good conservation status. Most of the studied sites demonstrated the favourable condition of characteristic lobelia vegetation (64\% of sites with FV status) and a lack of species indicating habitat degradation (60\% with FV; Fig. 3). Concerning characteristic plant community composition, less than $30 \%$ of sites were assessed as U1 and only 7\% (degraded lakes Czarne near Ostróda, Tyrsko and Dołgie Wielkie) as U2. As many as 30 of 43 lakes (71\%) have not shown any change in this indicator over the last 6-7 years. Undesirable species ("indicative of degradation") were found in 40\% of sites surveyed in 2016-2017 (17 sites, five of which rated as bad), whereas in the previous studies such species were found in $45 \%$ of sites (including only one at U2). This indicates that the phenomenon of the presence of undesirable species in the

Table 2. Summary of changes in the overall assessment of the conservation status and its parameters at the sites of the 3110 natural habitat where the monitoring surveys in the periods of 2009-2010 and 2016-2017 were performed

\begin{tabular}{lccc}
\hline \multicolumn{1}{c}{ Parameter } & \multicolumn{2}{c}{ Number of sites with the status change } \\
\cline { 2 - 4 } Habitat area & Improvement & Deterioration & No change \\
\hline Specific structure and functions & 0 & 6 & 37 \\
\hline Conservation prospects & 8 & 6 & 29 \\
\hline Overall assessment - conservation status & 5 & 10 & 28 \\
\hline
\end{tabular}




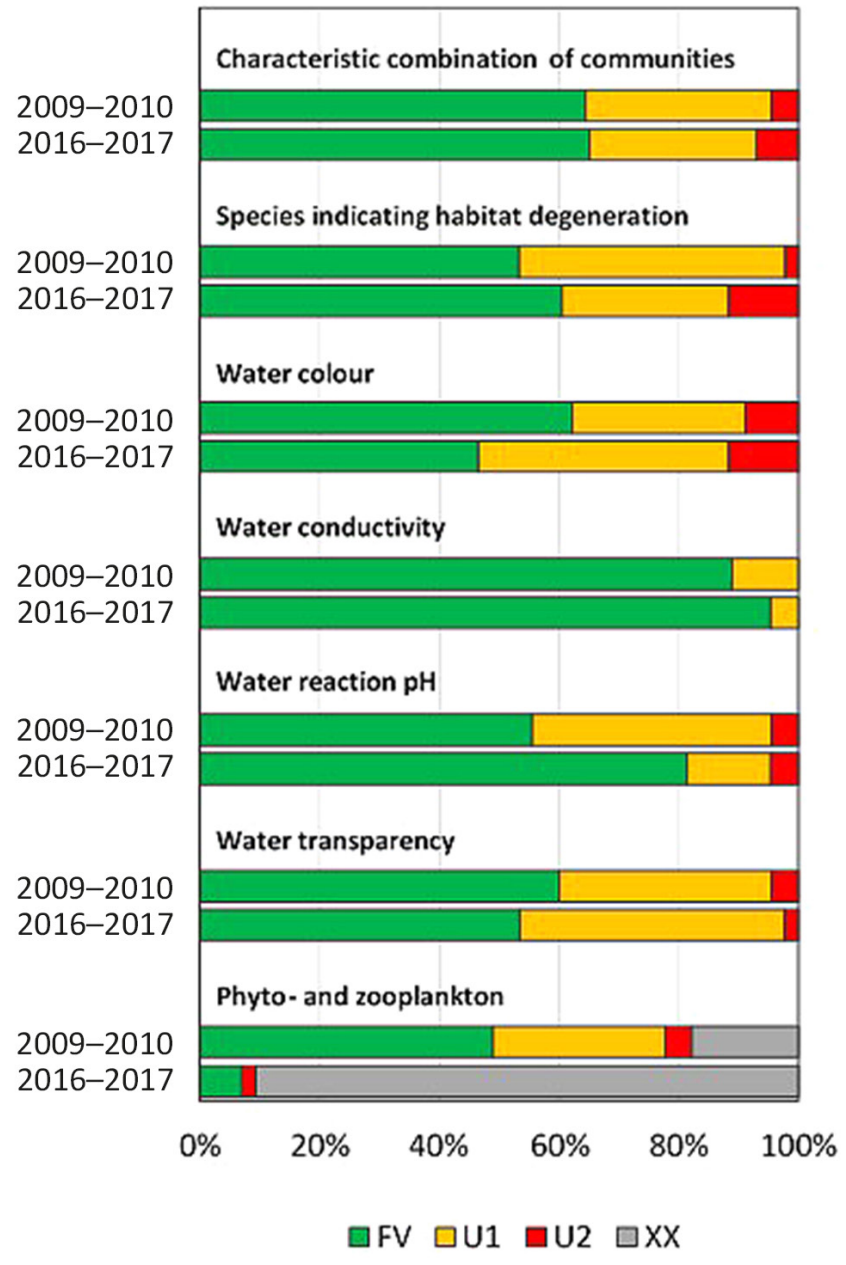

The proportion of 3110 sites classified as being in favourable (FV), inadequate (U1) or bad (U2) status based on the particular indicators of the parameter "Specific structure and functions" resulting from the monitoring surveys performed in the years 2009-2010 $(\mathrm{n}=45)$ and 2016-2017 ( $\mathrm{n}=43)$. XX denotes no data

stands is relatively stable in terms of quantity (similar number of "infected" sites in both research periods), but dynamic in quality (once infected the status of sites is deteriorated by the expansion of undesired species). The occurrence of species that indicate habitat degradation is generally associated with deterioration of water quality due to eutrophication (less dystrophisation) and plant remodelling as a result of the withdrawal of sensitive isoetids displaced by species more tolerant of lower water quality.

Of the water quality indicators, in the most recent surveys (2016-2017) conductivity and $\mathrm{pH}$ were rated FV in $95 \%$ and $83 \%$ of sites, respectively. The transparency of water was found in more than half of the surveyed sites (52\%) as FV, and only in one place (Dołgie Wielkie Lake), was the transparency of the waters bad $(0.2 \mathrm{~m})$. This was due to the progressive eutrophication process in connection with the cormorant colony occu- pying the lake. The highest proportion of sites assessed to be in unfavourable conditions $(52 \%$ at either U1 or U2) was due to water colour (Fig. 3).

Compared with the results of the previous monitoring trial, the indicators showed a high stability, with almost all of them indicating similar proportions of sites classified as FV, U1 and U2 between 2009-2010 and 2016-2017. Out of 43 sites examined in 2016-2017, 29 remained unchanged from the previous survey concerning the overall status of the Specific structure and functions parameter.

The "Conservation prospects" parameter demonstrated unsatisfactory assessment results as 14 sites (33\% of those surveyed in 2016-2017) were evaluated as unsatisfactory or bad in terms of protection perspective (Fig. 2). Despite the relatively good conservation status of habitat 3110 in Poland, inadequate protection in the short term can lead to habitat degradation. The most significant factor influencing the reduction of this parameter in lobelia lakes was a lack of effective protective measures, although in principle most of these lakes are covered by various forms of protection.

\section{Current and potential threats for the habitat 3110}

Recent pressures identified in the largest number of surveyed sites in 2016-2017 were those related to natural ecological processes, i.e., acidification (43\%), dryness (31\%) and eutrophication (21\%) as well as anthropogenic impacts associated with the use of LLs, i.e., fishing (45\%), trampling and destruction, paths, walking and cycling trails and scattered, often resting facilities (approximately $20 \%$ of sites). In most cases, these were the same pressures that were also recorded most often in the previous study. Lobelia lakes are usually characterized by high water quality and considerable landscapes, and therefore are attractive recreational areas. Excessive tourism, alongside natural processes such as succession or dystrophisation or accelerated eutrophication, is the major anthropogenic threat to this habitat. The intensity of the particular pressures and their impact on ecosystems were also very similar in both study periods. On the other hand, the pressure of eutrophication has been intensified (more impact is assessed as A, whereas in previous studies it was mainly B).

Attention is drawn to the effect of drying, which has not been reported at all in previous studies and was found in 13 locations in 2016-2017. This phenomenon was due to the generally observed changes in the hydrological regime and the decrease in the water level (a phenomenon of a global nature). The other impacts (35 types of impacts) were identified on an occasional basis (1-3 sites). 


\section{Summary and methodological conclusions}

Monitoring of the 3110 nature habitat in Poland confirms its susceptibility to changes and division of the habitat into several subtypes resulting from this sensitivity. The lessons learned from the first two trials of the monitoring indicate that the proper assessment of this habitat requires cooperation with experts experienced in taxonomy and ecology of lobelia vegetation. Additional problems in identifying some characteristic species are associated with the difficulty of finding these species and actually confirming their presence. In this situation, the most recommended method of searching for indicator species is diving. This method, although difficult to implement in routine monitoring, should be considered as the most appropriate methodological solution for exploring communities of isoetids.

Generally, the monitoring methodology used so far is highly appreciated as appropriate and effective in the assessment of the conservation status of the 3110 nature habitat in Poland. However, small modifications aimed at improvement of the methodology have been suggested.

Firstly, the urgent need to define the parameter "Habitat area" emerged, as this parameter is not strictly defined and therefore highly uncertain. Because no sitespecific reference vales were set to evaluate changes in this parameter, its assessment is highly subjective and intuitive. Evaluating the changes in the area of the habitat by changes in the depth of vegetation is proposed. The reduction of the settlement depth will reflect the rate of change of habitat range in the stand. For this, it is highly recommended that the list of indicators is complemented with an additional factor, i.e., maximum colonisation depth of aquatic vegetation, which is considered a reliable indicator of aquatic habitat condition (Canfield et al. 1985).

Secondly, the legitimacy of performing phytosociological relevés in aquatic habitats requires additional discussion. In contrast to terrestrial habitats, where the diagnostic and information value of such relevés are indisputable, in the case of aquatic habitats, the utility of a phytosociological approach is not as obvious. Most aquatic species form almost monospecific stands, the occurrence of which is strongly dependent on the water depth. Hence, three relevés performed in three depth zones would potentially represent three different communities, providing no complex information about mutual relationships among ecological/taxonomic groups of vegetation within the phytolitoral. The sequence and depth range of plant communities along the depth profile seem to be much more informative for monitoring purposes. Therefore, it is highly recommended that instead of performing three separate relevés within a transect, one relevé across the entire transect (transect $=$ relevé area) is examined.

Thirdly, it is suggested that for the indicator of water transparency the requirements for favourable status (FV) are redefined by including depth-specific values. As far as the current criterion of $3.5 \mathrm{~m}$ visibility for deep lakes is concerned, in the case of shallow lakes this may be difficult to achieve even in a very well preserved habitat. We propose the introduction of a FV boundary value for water transparency of $>3.5 \mathrm{~m}$ for deep lakes with a maximum depth $>5 \mathrm{~m}$ and water transparency to the bottom for shallow lakes.

Lastly, the methodology recommends a frequency of monitoring "every three years" with the possibility of increasing it to an annual survey in the case of sites indicating degradation. The stakeholder indications specify a frequency of four to six years. Taking into account the organizational and financial possibilities of monitoring in Poland, it seems that this frequency (4-6 years) is sufficient to track the trends of habitat change in the sites. It shoud be emphasised that more frequent monitoring will not improve the degraded sites and more effort should be put into the restoration measures than the monitoring.

\section{Acknowledgements}

This study was performed as a part of the project entitled: "Monitoring of species and habitat types with particular regard to the special areas of conservation of the Natura 2000 network in the years 2015-2018 in the field of natural habitats 2016-2018" executed at the order of the Chief Inspectorate for Environmental Protection in Poland and financed by the National Fund for Environment Protection and Water Management. Special thanks go to prof. Marek Kraska for his very useful advice and suggestions during the preparation of this publication and to Sebastian Kutyła who supported us in preparing the map of site location. Dr Jan Dziedzic and dr Anna Źróbek-Sokolnik are warmly acknowledged for their support during the field surveys.

\section{References}

Bociąg K., 2003, The impact of the acidic organic matter on the diversity of underwater vegetation in soft water lakes, Acta Soc. Bot. Pol. 72(3): 221-229.

Bociąg K., Borowiak D. (eds), 2016, Jeziora lobeliowe w drugiej dekadzie XXI wieku (Lobelia lakes in the second decade of the 21st century), FRUG, Gdańsk, 175 pp (in Polish, English summary).

Canfield D.E., Langland K.A., Linda S.B., Haller W.T., 1985, Relations between water transparency and maximum depth of macrophyte colonization in lakes, J. Aquat. Plant Manage. 23: 25-28. 
[EC] European Commission, 1992, Council Directive 92/43/ EEC of 21 May 1992 on the conservation of natural habitats and of wild fauna and flora, Offic. J. Eur. Communities L206: 7-50.

[EC] European Commission, 2013, Interpretation Manual of European Union Habitats - EUR28, European Commission, DG Environment, Nature ENV B.3, Brussel, 144 pp.

Kraska M. (ed.), 1994a, Jeziora lobeliowe. Charakterystyka, funkcjonowanie i ochrona. Część I (The lobelia lakes. Characteristics, functioning and protection. Part I), Idee Ekol. 6(4): 9-177 (in Polish, English summary).

Kraska M. (ed.), 1994b, Jeziora lobeliowe. Charakterystyka, funkcjonowanie i ochrona. Część II (The lobelia lakes. Characteristics, functioning and protection. Part II), Idee Ekol. 7(5): 9-105 (in Polish, English summary).

Kraska M., 2004, Jeziora lobeliowe (Lobelia lakes), [in:] Herbich J. (ed.), Siedliska przyrodnicze. Poradniki ochrony siedlisk i gatunków Natura 2000 - podręcznik metodyczny. Tom 2: Wody słodkie i torfowiska (Natural habitats. Guides for the protection of habitats and Natura 2000 species - A methodological handbook. Vol. 2: Freshwaters and peat bogs), Ministerstwo Środowiska, Warszawa: 29-36 (in Polish).

Kraska M., Klimaszyk P., Piotrowicz R., 2013, Anthropogenic changes in properties of the water and spatial structure of the vegetation of the lobelia lake Lake Modre in the Bytów Lakeland, Oceanogr. Hydrobiol. Stud. 42(3): 302-313.

Kraska M., Piotrowicz R., 2000, Jeziora lobeliowe: specyfika, trofia, roslinność i problemy ochrony (Lobelia lakes: specifty, trophy, vegetation and problems of the preservation), [in:] Ochrona jezior i mokradeł Pomorza Środkowego (Preservation of lakes and bogs of the Central Pomerania) Tow. Ekologiczno-Kulturalne w Bobolicach, Bobolice Biul. 3: 5-27 (in Polish).

Kraska M., Piotrowicz R., Klimaszyk P., 1996, Jeziora lobeliowe w Polsce (Lobelia lakes in Poland), Chrońmy Przyr. Ojcz. 52(3): 5-25 (in Polish, English summary).
Mróz W. (ed.), 2013, Monitoring of natural habitats. Methodological guide, GIOŚ, Warszawa, $97 \mathrm{pp}$.

Smolders A.J.P., Lucassen E.C.H.E.T., Roelofs J.G.M., 2002, The isoetid environment: biogeochemistry and threats, Aquat. Bot. 73(4): 325-350.

Szmal Z., Szmal B., 1965, Badania hydrochemiczne jezior lobeliowych województw gdańskiego i koszalińskiego (Hydrochemical investigations of lobelia lakes of the Gdańsk and Koszalin Provinces), Prace Kom. Biol. PTPN 30: 1-55 (in Polish, English summary).

Szmeja J., 1992, Struktura, organizacja przestrzenna i demograficzna populacji isoetydów. Studium ekologiczne roślin podwodnych (Structure, spatial organization and demography of isoetid populations. Ecological studies of submerged aquatic plants, Rozpr. Monogr. 175, Wydaw. UG, Gdańsk, 137 pp (in Polish, English summary).

Szmeja J., 1996, Rejestr polskich jezior lobeliowych (Register of Polish lobelia lakes), Fragm. Flor. Geobot. Ser. Polonica 3: 347-367 (in Polish).

Szmeja J., 1997, Evolution and conservation of lobelia lakes in Poland, Fragm. Flor. Geobot. 40(1): 89-94.

[UN] United Nations, 1992, Convention on Biological Diversity (CBD), United Nations Conference on Environment and Development (UNCED), Rio de Janeiro, 28 pp.

Wilk-Woźniak E., Kraska M., Piotrowicz R., Klimaszyk P., 2012, 3110 Jeziora lobeliowe (3110 Lobelia lakes), [in:] Mróz W. (ed.), Monitoring siedlisk przyrodniczych. Przewodnik metodyczny. Część druga (Monitoring of natural habitats. Methodological guide. Part two), GIOŚ, Warszawa: 114-129 (in Polish).

Wilk-Woźniak E., Kraska M., Piotrowicz R., Klimaszyk P., 2013, 3110. Lobelia lakes - Oligotrophic waters containing very few minerals of sandy plains (Littorelletalia uniflorae), [in:] Mróz W. (ed.), Monitoring of natural habitats. Methodological guide for 5 natural habitats: 3110 , 6210, 6520, 7230 and 9180, GIOŚ, Warszawa: 30-44. 